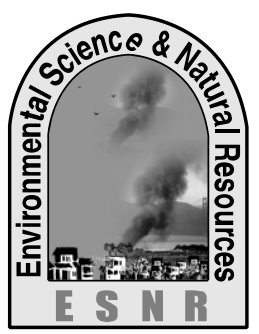

\title{
Spatial Effects of Industrial Effluent on Soil Quality around the Textile Industrial Area of Bhaluka Upazila, Mymensingh
}

\author{
N. Tabassum, R. Khatun" and M. A. Baten
}

Department of Environmental Science, Bangladesh Agricultural University, Mymensingh

*Corresponding author: rehana_envsc@yahoo.co.uk

\begin{abstract}
The study was carried out to investigate the spatial effects of industrial effluent on physico-chemical properties of soil around the textile industrial area of Bhaluka upazila, Mymensingh, from January to March, 2015. Total 15 soil samples were collected at $0 \mathrm{~m}, 50 \mathrm{~m}, 100 \mathrm{~m}, 200 \mathrm{~m}$ and $300 \mathrm{~m}$ distances from the effluent discharging point. Soil texture, $\mathrm{pH}$, electrical conductivity (EC), organic matter $(\mathrm{OM})$, nitrogen $(\mathrm{N})$, phosphorus $(\mathrm{P})$, potassium $(\mathrm{K})$, sulphur $(\mathrm{S})$, sodium $(\mathrm{Na})$ and heavy metal (lead, Pb and cadmium, Cd) content were investigated in this study. Soil pH, EC, OM and nutrient content of soil were higher at discharge point (at $0 \mathrm{~m})$ and lowest at $300 \mathrm{~m}$ distance. The $\mathrm{Pb}$ content was maximum $(36.9 \mathrm{ppm})$ at $0 \mathrm{~m}$ and minimum $(24.27 \mathrm{ppm})$ at $300 \mathrm{~m}$ distance. The highest value $(3.0 \mathrm{ppm})$ of $\mathrm{Cd}$ was observed at $0 \mathrm{~m}$ and lowest value $(2.8 \mathrm{ppm})$ was at $300 \mathrm{~m}$ distance. All of the studied values were higher at the adjacent of industrial area and gradually decreased with distance.
\end{abstract}

Key words: Industrial effluent, Soil's physical and chemical properties, Spatial effect

\section{Introduction}

Bhaluka is a newly industrial growing site of Bangladesh with unregulated growth of commercial industrial installations. The untreated effluents from these industries are discharged randomly to the nearby fields and the local streams and rivers. Industrial effluents consist of many trace and heavy metals like $\mathrm{N}, \mathrm{P}, \mathrm{K}, \mathrm{S}, \mathrm{Na}, \mathrm{Zn}, \mathrm{Cu}, \mathrm{Ni}, \mathrm{Cd}, \mathrm{Cr}, \mathrm{Pb}$, As, Fe etc. which may beneficial at minute amount and harmful at large amount. Metals such as $\mathrm{As}, \mathrm{Pb}$, $\mathrm{Cd}, \mathrm{Ni}, \mathrm{Hg}, \mathrm{Cr}, \mathrm{Co}, \mathrm{Zn}$ and $\mathrm{Se}$ are highly toxic even in minor quantity (Bharti et al., 2013). In most cases, metal levels were found to exceed the common regulation guideline levels enforced by many countries (Kabir et al., 2012). The waste material discharges from industrial activities may cause adverse effects on soil. Metal concentrations in contaminated soils may decrease soil microbial activity, soil fertility, crop yield and affect food quality and safety. Textile industries consume a large quantity of water and generate a huge amount of wastewater, which are generally discharged into the vicinity of industrial area. Dyeing process usually contributes $\mathrm{Cr}, \mathrm{Pb}, \mathrm{Zn}$ and $\mathrm{Cu}$ to wastewater (Benavides, 1992). Bhaluka upazilla also suffers from flooding during rainy season and thereby the industrial effluents spread over a large area. It is therefore essential to assess the soil quality over a large area. The objective of this study was to investigate the spatial variation of physicochemical properties of soil around the textile industrial area of Bhaluka Upazila.

\section{Materials and Method}

The study area is located in Habirbari union of Bhaluka upazila, Mymensingh within the latitude of $24^{\circ} 22^{\prime} 30^{\prime \prime} \mathrm{N}$ and longitude of $90^{\circ} 22^{\prime} 40.08^{\prime \prime} \mathrm{E}$. It has an area of $444.05 \mathrm{sq} . \mathrm{km}$. There are several types of industrial units in this area including textile, dyeing, pharmaceuticals, cosmetics, aluminum, ceramics, leather, glass, garments, packaging industry and brick fields.

\section{Collection, preparation and analysis of soil sample}

Fifteen soil samples were collected from $0-30 \mathrm{~cm}$ soil depth at $0 \mathrm{~m}, 50 \mathrm{~m}, 100 \mathrm{~m}, 200 \mathrm{~m}$ and $300 \mathrm{~m}$ distances around industrial area. After collection, the samples were carried to the laboratory of Department of Environmental Science, Bangladesh Agricultural University, Mymensingh, dried at room temperature, ground and sieved with a $2 \mathrm{~mm}$ sieve. The prepared samples were kept in polythene bags and labeling for laboratory studies. The samples were analyzed for physicochemical parameters viz. soil texture, soil $\mathrm{pH}$, electrical conductivity (EC), organic matter (OM), nitrogen $(\mathrm{N})$, phosphorus $(\mathrm{P})$, potassium $(\mathrm{K})$, sulphur $(\mathrm{S})$, sodium $(\mathrm{Na})$, lead $(\mathrm{Pb})$ and cadmium $(\mathrm{Cd})$. Soil texture was determined by hydrometer method; soil $\mathrm{pH}$ was determined by glass electrode $\mathrm{pH}$ meter (WTW $\mathrm{pH}$ 522; Germany); EC was determined electrometrically (soil water ratio was $1: 5$ ) by a conductivity meter (WTW LF 521; Germany); OM was calculated by multiplying the content of organic carbon by van Bemmelen factor, 1.724; $\mathrm{N}$ was determined by Kjeldahl method; available P was determined by Olsen's method colorimetrically; available $\mathrm{S}$ was determined by extracting the soil samples by calcium chloride solution $(0.15 \%)$; available $\mathrm{Na}$ and $\mathrm{K}$ was determined by flame photometer; total concentrations of $\mathrm{Pb}$ and $\mathrm{Cd}$ were determined using atomic absorption spectrophotometer (AAS), equipped with single elements hollow-cathode lamps at the wavelengths of 283.3 and $228.8 \mathrm{~nm}$, respectively.

\section{Results and Discussion}

Effect of industrial effluent on soil texture, soil pH and electrical conductivity $(\mathrm{EC})$

The textural classes of the study area ranged from silty clay loam to clay. The silt content was higher at discharge point; clay content was higher at $300 \mathrm{~m}$ distance and no significant variation was found in sand content among different location. The average $\mathrm{pH}$ value of soil sample was 7.3, 7.2, 7.1, 6.8 and 6.4 at $0 \mathrm{~m}, 50 \mathrm{~m}$, 
100m, 200m and 300m distance, respectively (Fig. 1a). Vertical bar indicates the standard error. The highest $\mathrm{pH}$ value (7.3) was found at $0 \mathrm{~m}$ distance which was slightly alkaline and the lowest value (6.4) was observed at $300 \mathrm{~m}$ which was slightly acidic. Various materials (wastes, effluents, chemicals and salt etc.) discharged from the industry might be responsible for higher $\mathrm{pH}$ at Om location. Kumar and Chopra (2010) investigated the influence of sugar mill effluent on physico-chemical characteristics of soil at Haridwar (Uttarakhand), India



where $\mathrm{pH}$ was 9.56. The average $\mathrm{EC}$ value of soil sample was $446.7\left(\mu \mathrm{scm}^{-1}\right), 424.33\left(\mu \mathrm{scm}^{-1}\right), 393.23$ $\left(\mu \mathrm{scm}^{-1}\right), 363.5\left(\mu \mathrm{scm}^{-1}\right)$ and $96.03\left(\mu \mathrm{scm}^{-1}\right)$ at $0 \mathrm{~m}$, $50 \mathrm{~m}, 100 \mathrm{~m}, 200 \mathrm{~m}$ and $300 \mathrm{~m}$ distance, respectively (Fig. 1b). The maximum value $\left(446.7 \mu \mathrm{scm}^{-1}\right)$ was found at $0 \mathrm{~m}$ and minimum value $\left(96.03 \mu \mathrm{scm}^{-1}\right)$ was at $300 \mathrm{~m}$ distance. According to Costa et al. (2001), high EC value in soil, might be due to the huge quantities of salt and solid wastes in textile and other industrial effluents.



Fig. 1. (a) Soil pH and (b) electrical conductivity (EC) at different distances of the study area

\section{Effect of industrial effluent on nutrient status of soil}

The average OM content was $2.78 \%, 2.34 \%, 2.09 \%$, $2.09 \%$ and $2.0 \%$ at $0 \mathrm{~m}, 50 \mathrm{~m}, 100 \mathrm{~m}, 200 \mathrm{~m}$ and $300 \mathrm{~m}$ distance, respectively (Fig. 2a). OM was higher at $0 \mathrm{~m}$ distance and it decreased gradually up to $100 \mathrm{~m}$ and after that the value was constant. The higher value at Om might be due to the deposition of large quantities of industrial wastes having higher OM (Sultana, 2012).
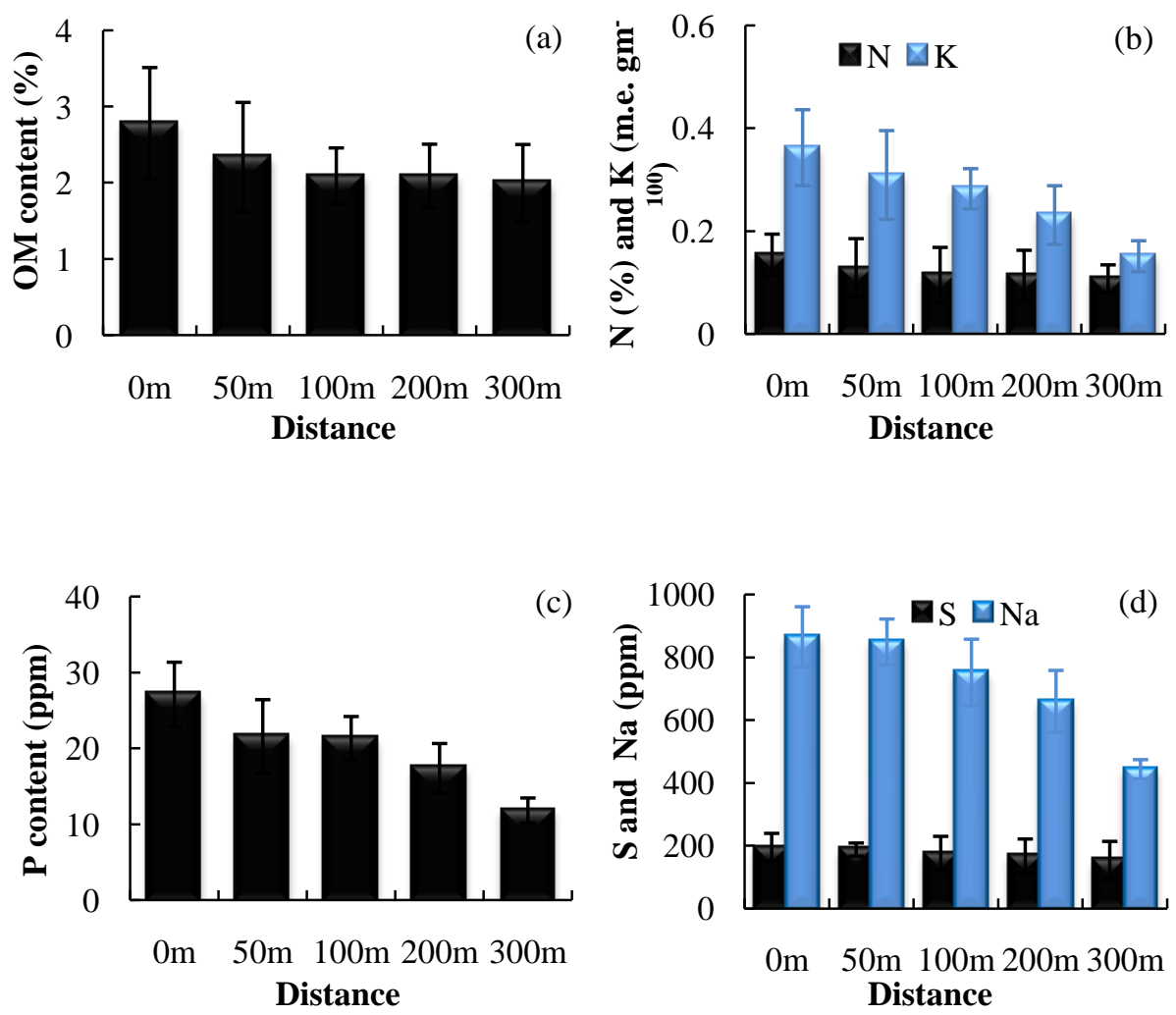

Fig. 2. (a) Organic matter $(\mathrm{OM})$; (b) nitrogen $(\mathrm{N})$ and potassium $(\mathrm{K})$; (c) phosphorous (P); (d) sulphur (S) and sodium $\mathrm{Na}$ content at different distances of the study area

The average $\mathrm{N}$ content was $0.154 \%, 0.128 \%, 0.114 \%$, $0.113 \%$ and 0.107 at $0 \mathrm{~m}, 50 \mathrm{~m}, 100 \mathrm{~m}, 200 \mathrm{~m}$ and $300 \mathrm{~m}$ distance, respectively (Fig. 2b). $\mathrm{N}$ content decreased from canal edge to distant places and the variation in $\mathrm{N}$ 
content with distance followed the variation in $\mathrm{OM}$ content. Rahman et al. (2012) found that nitrogen content varied from $0.024 \%$ to $0.88 \%$ in the close vicinity of Dhaka Export Processing Zone (DEPZ). The average $\mathrm{P}$ content was $27.10 \mathrm{ppm}, 21.59 \mathrm{ppm}, 21.3$ ppm, $17.38 \mathrm{ppm}$ and $11.82 \mathrm{ppm}$ at $0 \mathrm{~m}, 50 \mathrm{~m}, 100 \mathrm{~m}$, $200 \mathrm{~m}$ and $300 \mathrm{~m}$ distance, respectively (Fig. 2c). The maximum value was found at $300 \mathrm{~m}$ distance and minimum value was at $0 \mathrm{~m}$ distance. A significant variation in $\mathrm{P}$ content was found with distance. The result indicates the industrial origin of $\mathrm{P}$ at $0 \mathrm{~m}$. Sumi (2010) investigated the metallic contamination in some industrial soils of Gazipur district and reported that the mean $\mathrm{P}$ value was $18.86 \mathrm{ppm}$. The average $\mathrm{K}$ content was 0.362 (m.e. $\left.100 \mathrm{~g}^{-1}\right), 0.309$ (m.e. $\left.100 \mathrm{~g}^{-1}\right), \quad 0.282$ (m.e.g), 0.231 (m.e.100g $\mathrm{g}^{-1}$ ) and 0.151 (m.e.100g $\mathrm{g}^{-1}$ ) at $0 \mathrm{~m}, 50 \mathrm{~m}, 100 \mathrm{~m}, 200 \mathrm{~m}$ and $300 \mathrm{~m}$ distance, respectively (Fig. 2b). The mean $\mathrm{K}$ content decreased gradually with the increase of distance from waste discharge canal. The industrial effluent might contain higher $\mathrm{K}$ which increased the $\mathrm{K}$ content at $0 \mathrm{~m}$. The average $\mathrm{S}$ content was $195.13 \mathrm{ppm}, 187.5 \mathrm{ppm}, 175.5 \mathrm{ppm}, 167.16 \mathrm{ppm}$ and $153 \mathrm{ppm}$ at $0 \mathrm{~m}, 50 \mathrm{~m}, 100 \mathrm{~m}, 200 \mathrm{~m}$ and $300 \mathrm{~m}$ distance, respectively (Fig. 2d). S content showed a gradual decrease with the increase of distance from waste canal indicatin ${ }^{-100}$ the load of $\mathrm{S}$ at $0 \mathrm{~m}$ sites preferably from industrial effluent. However, the variation in $\mathrm{S}$ content was minimum with distance. The average $\mathrm{Na}$ content was $864.76 \mathrm{ppm}, 848.53 \mathrm{ppm}$, $751.26 \mathrm{ppm}, 659.36 \mathrm{ppm}$ and $443.2 \mathrm{ppm}$ at $0 \mathrm{~m}, 50 \mathrm{~m}$, $100 \mathrm{~m}, 200 \mathrm{~m}$ and $300 \mathrm{~m}$ distance, respectively (Fig. 2d). A significant variation in $\mathrm{Na}$ content was found with distance. There was a decreasing trend in $\mathrm{Na}$ concentration with increasing distance from waste canal.

\section{Effect of industrial effluent on heavy metal status of soil}

The average $\mathrm{Pb}$ content was $36.9 \mathrm{ppm}, 30.37 \mathrm{ppm}$, $29.07 \mathrm{ppm}, 28.1 \mathrm{ppm}$ and $24.27 \mathrm{ppm}$ at $0 \mathrm{~m}, 50 \mathrm{~m}, 100$ $\mathrm{m}, 200 \mathrm{~m}$ and $300 \mathrm{~m}$ distance, respectively (Fig. 3a). Higher $\mathrm{Pb}$ content at $0 \mathrm{~m}$ might be due to industrial effluents. Permissible limit of $\mathrm{Pb}$ content for agricultural soil is $100 \mathrm{ppm}$ and all the studied values were below the permissible limit. Mondol et al. (2011) examined the dry and wet season's average $\mathrm{Pb}$ content of industrially polluted soils of Tejgaon area and found that $\mathrm{Pb}$ content was $130.29 \mathrm{ppm}$ and $95.08 \mathrm{ppm}$, respectively.
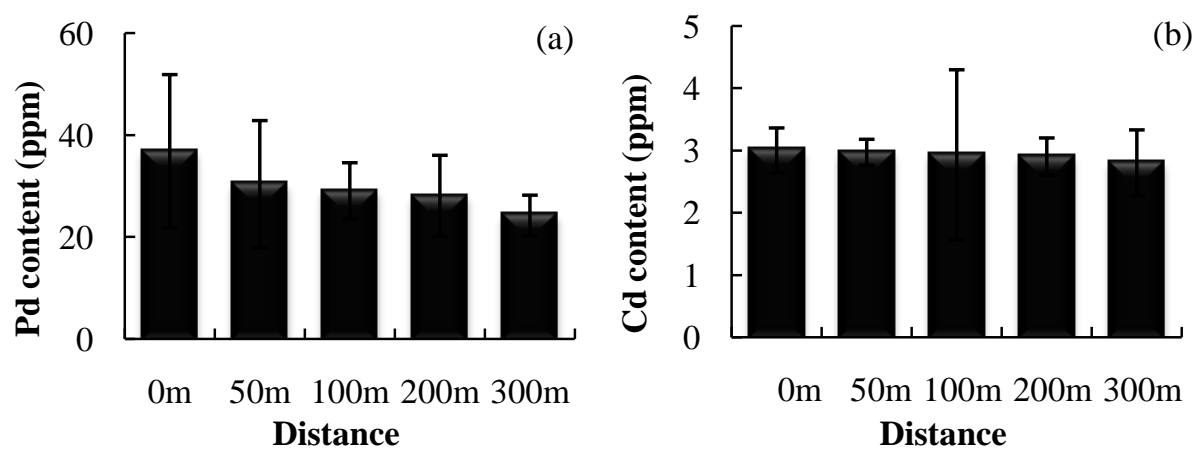

Fig. 3. (a) Lead $(\mathrm{Pb})$ and (b) cadmium (Cd) content at different distances of the study area

The average Cd content was $3.0 \mathrm{ppm}, 2.97 \mathrm{ppm}, 2.93$ ppm, $2.90 \mathrm{ppm}$ and $2.8 \mathrm{ppm}$ at $0 \mathrm{~m}, 50 \mathrm{~m}, 100 \mathrm{~m}, 200 \mathrm{~m}$ and $300 \mathrm{~m}$ distance, respectively (Fig. 3b). The standard limit of cadmium content for soil is $0.5 \mathrm{ppm}$. The $\mathrm{Cd}$ content in all studied samples was higher than the standard limit. $\mathrm{Pb}$ and $\mathrm{Cd}$ content exceeded the standard limits in textile and tannery industries effluents and associated soil located near Haridwar (Deepali and Gangwar, 2010).The Cd content was 404.35 ppm

\section{References}

Benavides, L. 1992. Expert Group meeting on Local Cottage Industries of Hazardous Wastes from Smallscale and Cottage Industries, An Overview.

Bharti, P. K. 2013. Impact of Industrial Effluents on Ground Water and Soil Quality in The Vicinity of Industrial Area of Panipat city, India. Journal of Applied and Natural Science, 5 (1): 132-136 . around the sugar mill industries, India (Kumar and Chopra, 2010).

\section{Conclusions}

All of the components were higher at $0 \mathrm{~m}$ distance and lower at $300 \mathrm{~m}$ distance. The huge quantities of wastes and sludge discharged from industries might be responsible for the enrichment of all studied physicochemical parameters at discharging point $(0 \mathrm{~m}$ location).

Costa, C. N.; Castilhos, D. D.; Castilhos, R. M.V.; Konrad, E. E.; Passianoto, C. C. and Rodrigues, C. G. 2001. Tannery sludge effects on soil chemical properties, matter yield and nutrients uptake by soybean. Revista Brasileira de Agrociencia, 7(3): 189-191. 
Deepali and Gangwar, K. K. 2010. Metals Concentration in Textile and Tannery Effluents, Associated Soils and Ground Water. New York Science Journal, 3(4):82-89.

Kabir, Ray, S. and Kim, K. 2012. Current Status of Trace Metal Pollution in Soils Affected by Industrial Activities. The Scientific World Journal, 2012:1-18.

Kumar, V. and Chopra, A.K. 2010. Influence of sugar mill effluent on physico-chemical characteristics of soil at Haridwar (Uttarakhand), India. Journal of Applied and Natural Science, 2 (2): 269-279.

Mondol, M. N.; Chamon, A. S.; Faiz, G.; Rahman, M. H. and Elahi, S. F. 2011. Fractionation, characterization and speciation of lead in the industrially polluted soils of Tejgaon Area of Bangladesh and lead pollution of associated plants and water. Bangladesh Journal of Scientific and Industrial Research, 46(3): 277-290.

Rahman, S. H.; Khanam, D. and Adyel, T. M. 2012. Assessment of Heavy Metal Contamination of Agricultural Soil around Dhaka Export Processing Zone (DEPZ), Bangladesh: Implication of Seasonal Variation and Indices. Applied Sciences, 2, 584-601.

Sultana, M. S.; Kulsum, U.; Shakila, A. and Islam, M. S. 2012. Toxic metal contamination on the river near industrial area of Dhaka. Universal Journal of Environmental Research and Technology, 2(2):5664.

Sumi, S. A. 2010. Toxic metallic contamination in industrial waste water and soils of some selected areas of Gazipur, Bangladesh. MS Thesis, Department of Agricultural Chemistry, Bangladesh Agricultural University, Mymensingh. 